\title{
PRELIMINARY REPORT ON THE NINETEENTH EXCAVATION SEASON OF THE ARCHAEOLOGICAL EXPEDITION TO WAD BEN NAGA
}

\author{
Pavel Onderka - Vlastimil Vrtal - Jiří Honzl ${ }^{1}$
}

\begin{abstract}
The nineteenth excavation season of the Archaeological Expedition to Wad Ben Naga primarily focused on the continued excavations of the so-called Isis Temple (WBN 300). The main aim was to confirm the assumptions that could have been made about the dimensions and disposition of the temple based on the results of previous excavation seasons. The second, southern, tower of the temple's pylon was uncovered. Similar to the northern one, it included a side entrance to the temple. Another trench was opened in the back of the temple confirming the position of another corner of the building. Outside the so-called Isis Temple (WBN 300), the works continued in gradual uncovering of structure WBN 250.
\end{abstract}

KEYWORDS: Sudanese archaeology - Meroitic period - Wad Ben Naga - Isis Temple (WBN 300)

\section{Introduction}

The nineteenth excavation season of the Archaeological Expedition to Wad Ben Naga took place between 22 November and 21 December 2020. Archaeological works were launched on 29 November 2020 and concluded on 18 December 2020.

The season was carried out under the guidelines for archaeological excavations as defined by the Ordinance for Protection of Antiquities of 1999. The archaeological field work was preceded by documentation works in the Sudan National Museum, namely preparations of accession of finds from the previous seasons at Wad Ben Naga into the inventory of the Sudan National Museum and selection of objects from Wad Ben Naga for the new display of the Sudan National Museum.

The works at Wad Ben Naga were preceded by a short visit to the archaeological site of Jebel Qeili, during which the interior of the cave located in the vicinity of the boulder with the Shorkaror carving was digitally documented. Several painted figures of the god Amun were identified and documented on the eastern wall of the shelter.

1 Contacts: Pavel Onderka \& Vlastimil Vrtal \& Jiří Honzl, National Museum - Náprstek Museum of Asian, African and American Cultures, Ancient Near East and Africa Collection, Prague, Czech Republic; e-mail: pavel.onderka@nm.cz, vlastimil.vrtal@nm.cz, jiri.honzl@nm.cz. The article was written within the framework of the project 'The Building Program of King Natakamani and Queen Amanitore' supported by the Czech Science Foundation (grant no. 18-00454S). The Archaeological Expedition to Wad Ben Naga wishes to express its sincerest thanks and gratitude to the National Corporation for Antiquities and Museums, namely to Dr. Hassan Hussein Idris, Dr. Abdel-Rahman Ali Mohamed, Dr. Hatem el-Nour, Juweriya Osman, Iglal Malik, and Ikhlass Abdellatif, and Dr. Nasreldin Shulgami, the Honorary Consul-General of the Slovak Republic in the Republic of the Sudan. 
The mission was headed by Pavel Onderka (director) and Juweriya Osman (inspector of the National Corporation for Antiquities and Museums), and further consisted of Vlastimil Vrtal (archaeologist) and Jiří Honzl (archaeologist).

The works of the nineteenth season focused on [1] the continued excavations of the so-called Isis Temple (WBN 300), [2] continued excavations of the structure WBN 250 [Fig. 1], and [3] removing of two large sandstone blocks (once forming the architrave above the altar niche in the Typhonium's hall of offerings (WBN 201) to the ghafir's house (to be later moved to the Sudan National Museum [hereafter 'SNM'] and exhibited in its new display; Inv. No. 36347 [indexed]).

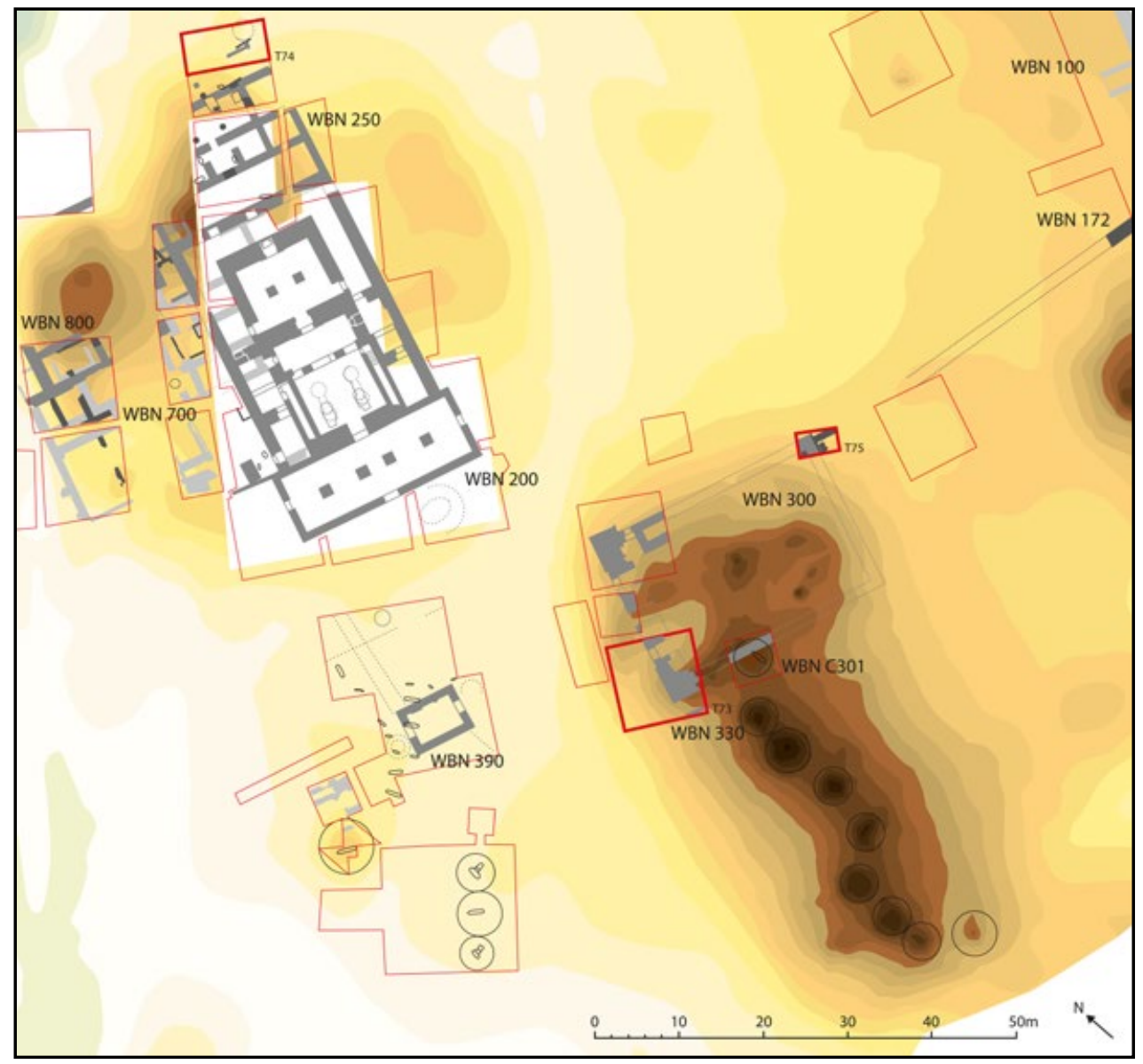

Fig. 1. Western part of Central Wad Ben Naga. Trenches excavated during the nineteenth excavation season are highlighted in bold red. (Illustration: Pavel Onderka, Vlastimil Vrtal, Gabriela Vrtalová, and Jiří Honzl). 


\section{[1] The continued excavations of the so-called Isis Temple}

Following the conclusion of archaeological works in the so-called Typhonium at Wad Ben Naga (WBN 200), the Expedition focused its main attention to rediscovery and exploration of the so-called Isis Temple (WBN 300), which had been briefly excavated by the Royal Prussian Expedition, headed by Carl Richard Lepsius, on 19 March $1844 .^{2}$

It was in the remains of this temple that the Lepsius expedition discovered the famous Altar A (an actual bark stand; Egyptian Museum and Papyrus Collection, Inv. No. 7261) with the name of the goddess Isis (hence the Isis Temple) and the bilingual names of King Natakamani and Queen Amanitore.

A second altar with the names of the goddess Hathor, known as Altar B, was originally discovered here as well (SNM, Inv. No. 36350 [indexed] - fragments). Its remains were discovered by the Archaeological Expedition to Wad Ben Naga during exploration of the western part of Central Wad Ben Naga. ${ }^{3}$

\section{Recapitulation of previous works}

During the fifteenth excavation season (Autumn 2017), ${ }^{4}$ a geophysical survey of Central Wad Ben Naga was carried out. ${ }^{5}$ The survey indicated a rectangular structure situated in front of the anticipated location of the Isis Temple. During the sixteenth excavation season (Spring 2018), ${ }^{6}$ Meroitic Kiosk WBN 390 with adjacent cemeteries of later dates (WBN C260) ${ }^{7}$ were unearthed.

During the seventeenth ${ }^{8}$ and eighteenth ${ }^{9}$ seasons (Autumn 2018 and Autumn 2019, respectively), the exploration of the proper temple [Fig. 2] began. In trench T64, which was explored during both lastly mentioned seasons, ca. two thirds of the pylon's northern tower were unearthed. A special feature of the tower was an entrance inserted in it, dislocated from the main axis of the temple, as indicated by the axis of Kiosk WBN 390. The discovery of the side entrance immediately suggested a possible parallel between temple WBN 300 and the Isis Temple at Philae, where a side entrance in one of the First Pylon's towers led to the so-called birth house (in Egyptian archaeology termed as a mammisi).

The lowermost register of the relief decoration of the sandstone door jambs was furnished with depictions of fecundity figures, representing fertility of the Nile.

In the façade of the northern tower, there was a block of ferriferous sandstone bearing an Egyptian inscription organized into five columns. The text represented an abridged version of the inscription from the flagpole niche in the façade of the First Pylon of the Isis Temple at Philae, ${ }^{10}$ a fact which represents another connection between the two temples. The preserved part of the text contained the name of the goddess Isis. ${ }^{11}$

\footnotetext{
2 Lepsius 1849-1859, V, pp. 337-338, X, Taf. 55; Erbkam 2007, 19 March 1844.

3 Onderka et al. 2014b, p. 142, Cat. No. 48. The very first fragment of Altar B was discovered in the course of the fourth excavation season; Onderka 2013, pp. 8-9, Pl. 8.

4 Onderka et al. 2018b, p. 144.

5 Ullrich et al. 2018.

6 Onderka et al. 2019a, pp. 134-137.

7 See Jungová 2020.

8 Onderka et al. 2019b: pp. 108-109.

9 Onderka et al. 2020, pp. 68-72.

10 Junker 1958, p. 17.

11 Onderka et al. 2021, Pl. 1.
} 


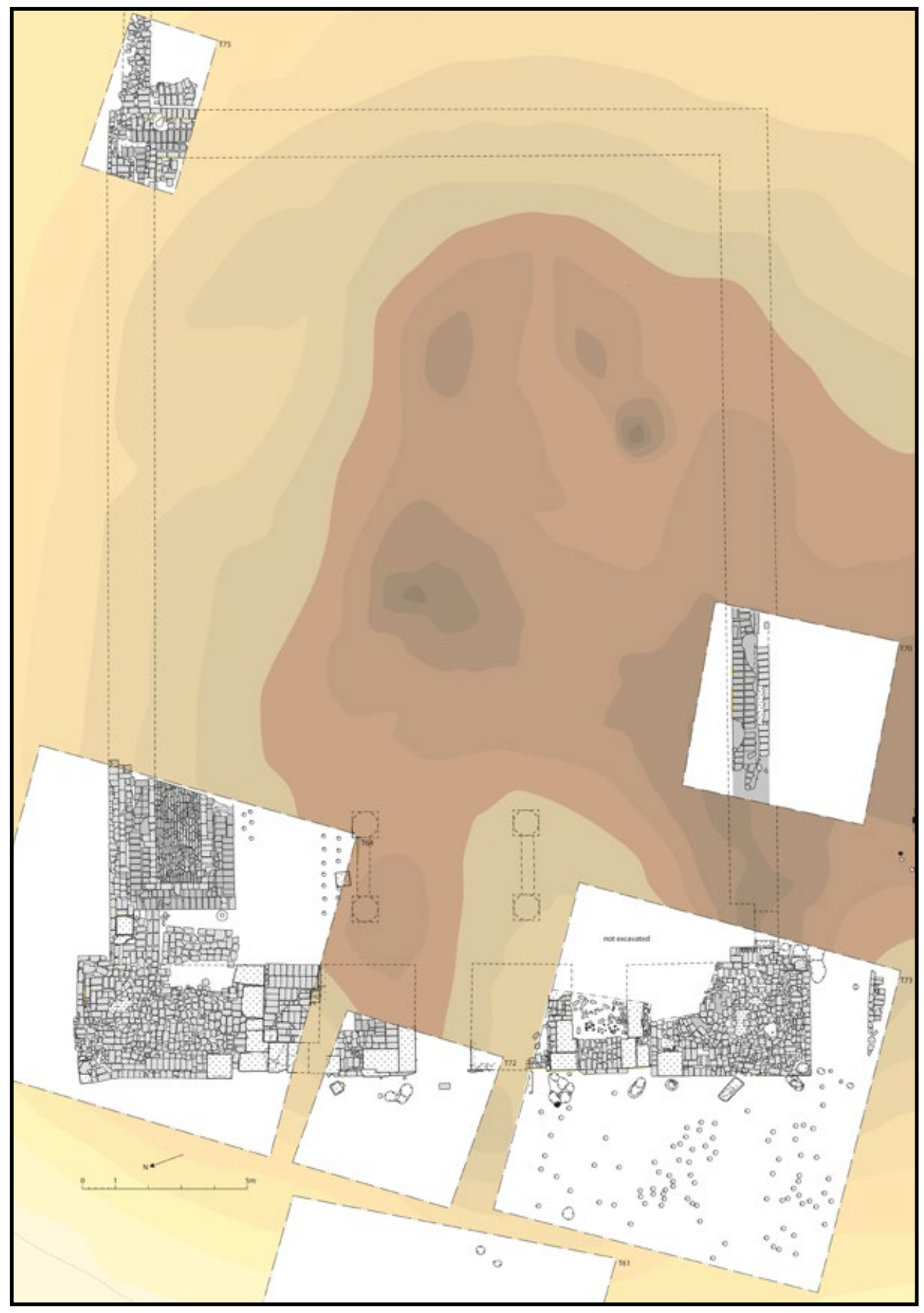

Fig. 2. Top plan of the Isis Temple after the completion of the nineteenth excavation season. (Illustration: Pavel Onderka, Vlastimil Vrtal, Gabriela Vrtalová, and Jiří Honzl). 
The architectural analogy, as well as the copy of the text from Philae together with the inscriptions on Altar A, may indeed indicate that temple WBN 300 was dedicated to Isis.

Besides the side entrance inserted into the pylon, a much smaller and less elaborate side door to the anticipated hypostyle hall was located, as it was the case of many Meroitic temples, ${ }^{12}$ in the north outer wall of the temple. East of the pylon, a large, layered mud brick structure was found. The core of the structure consisted of fired and mud bricks placed on their long narrow sides. They were surrounded by a wall made of regularly placed mud bricks (fired bricks were used for corners only). The northern, i.e. exterior, side of the temple's surrounding wall was equipped with fired brick casing. Plaster was applied on the fired brick surface and bore both relief and polychrome decorations. The polychrome decoration was carried out in red, yellow, and blue.

In the explored part of the hypostyle hall, fragments of a single column were discovered. It was placed on a rectangular base; the column shaft consisted of several drums which bore figural decoration accompanied by Egyptian texts. The texts represented direct speeches of the depicted figures and possibly captions to their depictions.

Still during the eighteenth season, the main gate of the temple along with the remaining part of the pylon's northern tower were uncovered in trench T72. The main door was decorated with figures of divine and royal figures as well as with Egyptian texts. The most substantial texts which was preserved on one of the collapsed blocks provided the phrase 'supporting the sky as (the god) Shu (does)' (rmn p.t mj šw). The phrase relates to the main iconographical theme of Altars $A$ and $B$, namely the act of the supporting of the sky (by the ruling couple of King Natakamani and Queen Amanitore, and two goddesses). ${ }^{13}$ This act may play an important role in the interpretation of both the cultic centre at Wad Ben Naga in general, and the so-called Isis Temple (WBN 300) in particular.

Within the preparations of the exploration of temple WBN 300, the cemetery WBN C300, most likely of a Post-Meroitic date, needed to be explored first. The exploration took place during the eighteenth excavation season. The superstructure of the tumulus WBN C301 was dismantled and the burial of an adult individual from the grave was retrieved. During the excavation works, the top of the temple's south exterior wall was reached.

Within the stone rings of the tumulus WBN C301, a fragment of Altar B (F19/003) was discovered. This fragment had been broken off from the altar before it was discovered by the Lepsius expedition in 1844. It is with all probability that the stone was moved from its original location upon the construction of the tumulus WBN C301.

By the time the works of the eighteenth season came to an end, a substantial amount of information had already been gathered. These pieces of information allowed to revise Lepsius's assessment of archaeological situation, as well as Priese's suggested reconstruction. ${ }^{14}$ Enough data has been collected to estimate the temple's dimensions (length of the temple: $29.5 \mathrm{~m}$, width of the pylon: $21.95 \mathrm{~m}$; width of the temple: $20.2 \mathrm{~m}$ ).

12 See Rocheleau 2008, Figs. 28, 34, 41.

13 See Kurth 1975.

14 See Priese 1984. 


\section{Current works: Trench T73}

Planning of works in the following season heavily benefited from the outcomes of the previous years. Trench T73 $(10.0 \times 10.0 \mathrm{~m}$; north-east corner of the square, covering the south-west corner of the Hypostyle Hall [WBN 301] remained unexcavated) [Fig. 3], newly opened during the nineteenth season, covered almost entirely the southern tower of the temple's pylon. Its western part captured space in front of the temple with several groups of postholes hollowed into the local bedrock (sīra). The remains of the pylon's tower located in the eastern part of the square were preserved into the substantial height of ca. $1.8 \mathrm{~m}$.

The mass of the tower (FEA 277) was constructed of fired bricks, while in the core an amount of mud bricks was employed. The walls of the tower were sloping inwards. The façades of the pylon were covered with a layer of plaster which was formed into relief bearing polychrome decoration in red, blue, and yellow (for the spectrum of motives see below). The plaster seems to have been applied in several layers [Pl. 1].

The southern tower - analogically to the northern tower - had a gateway inserted in it. As a matter of fact, the temple had three concentric entrances - the main entrance located on the axis of the temple (complex) and two side entrances embedded into both towers of the pylon. This layout diverts from the considered pattern of the temple, i.e. the Isis Temple at Philae. The southern side entrance would correspond to the so-called Gate of Philadelphus, standing in front of the First Pylon's eastern tower [Pl. 8].

The southern side entrance was badly preserved. Only remains of the door jambs (FEA 280) were still in situ. On one of the blocks from the south jamb of the gateway (which was made of a considerably higher quality sandstone than the others), an upper part of a fecundity figure was found. The desolate state of preservation of the gateway might have been caused by a collapse of an adjoining column of the hypostyle hall (WBN 301) into it. Fragments of a column base, as well as of column drums have been discovered in the gateway.

Among the sandstone blocks discovered in the gateway area were also parts of an architrave with a cavetto cornice, which once decorated the entrance. The passage was paved with fired bricks (FEA 286), which was one major difference in comparison with the gateway in the northern tower of the pylon, which was paved with large stone blocks. On both sides of the side entrance in front of the temple, vessels were inserted into the floor/bedrock (FEA 287).

To the south of the southern side entrance was a pillar (FEA 281; consisting of two ferriferous sandstone blocks) which bore five columns of an Egyptian hieroglyphic text. The pillar represented the concentric counterpart for the block beside the northern side entrance. Out of the five columns of the Egyptian text on the southern pillar, only parts of three were still legible. The texts were applied in a rather thin layer of outdoor plaster, and not carved into the stone. The text, again representing an abridged version of the flagpole niche texts, included a phrase 'give the office of (Horus ?)' (rdjt j3w.t n(.t) [hrw ?]) [Pl. 2].

The pylon's southern tower was richly decorated. Thanks to the fragments retrieved in the western part of the square, the original theme of the pylon's decoration could have been identified. The decoration's lowermost register could be well established, as a part of it has been preserved in situ. Remains of a shield (usually crowned with an upper part of a prisoner's-of-war body) was found. It was modelled in plaster on the casing of the pylon just next to the pillar with the 
hieroglyphic inscription. Six to seven shields would fit into the lowermost register of the tower's decoration. ${ }^{15}$

Several hundreds of fragments of outdoor plasters with relief and polychrome decoration have been retrieved from the trench. They included parts of human body [Pls. 3-4], pieces of clothing and personal adornments [Pl. 5], as well as parts of animal bodies (feather, mane ?). The high frequency of hands expressing the characteristic supplicant gesture [Pl. 6] among the repertoire indicates that the scene originally bore the usual depiction of a Meroitic sovereign (king or queen) smiting their enemies. The decorations on the Apedemak temple at Naga may serve as a possible comparison [Pl. 7]. ${ }^{16}$

Similar to the context of the northern tower, a small side entrance was located behind the pylon's southern tower. The doorway was paved with a limestone threshold (FEA 288).

In the southeast corner of the trench, remains of another structure (WBN 330) were discovered. The feature consisted of two lines of fired bricks preserved into the height of two courses (FEA 289). The structure WBN 330 appears to be aligned with the socalled Isis Temple (WBN 300).

\section{Current works: Trench T75}

Trench T75 [Fig. 4] was set at the north-eastern foot of kom C, where the location of the back corner of the temple could be estimated. Besides confirmation of this assumption, the second goal of the excavation was to determine whether there is a connection between the so-called Isis Temple (WBN 300) and the wall WBN 172, ${ }^{17}$ which was running from the south-western corner of the Palace of Amanishakhete (WBN 100) towards west in the general direction of the anticipated corner of the so-called Isis Temple (WBN 300). Trench T75 covered an area of $5.0 \times 3.0 \mathrm{~m}$. Modest remains of what appeared to be a fired brick destruction were visible on the surface.

In the western part of the trench, immediately under the surface, the excavation revealed a brick structure, which consisted of a fired brick casing and a mudbrick core with outdoor plaster covering both its outer and inner sides (FEA 288). The feature could be apparently identified with the temple's north-eastern corner. It was preserved to the height of six to seven courses of brickwork above the ground. The outer faces of the corner were heavily damaged, and the very outer corner of the building was, above the level of foundations, completely dismantled. Two displaced corner bricks with torus moulding, one almost complete and one partial, were found nearby evidencing its original design. The processes which caused the damage to the walls had stronger impact in two areas where they created conspicuous large holes in the brickwork, one located on each side of the outer corner in the distance matching the thickness of the walls. They could be tentatively identified as created by flowing water. As it seems, at some point during the decay of the building, the water torrents from seasonal rains were directed to flow from the top of the then extant structure through both areas near the corner of the building. The walls were set on raised foundations protruding in front

15 For the sake of comparision, one can turn to the Apedemak Temple at Naga or to the Sun Temple at Meroe; Lepsius 1949-1959, X, Taf. 56; Garstang 1911, Pl. XXXIV.

16 Lepsius 1949-1959, X, Taf. 56; Gamer-Wallert 1983, Bl. 1-2.

17 Onderka 2016, p. 39, Fig. 25; Onderka et al. 2019b, pp. 111-112, Fig. 4, Pl. 4. 


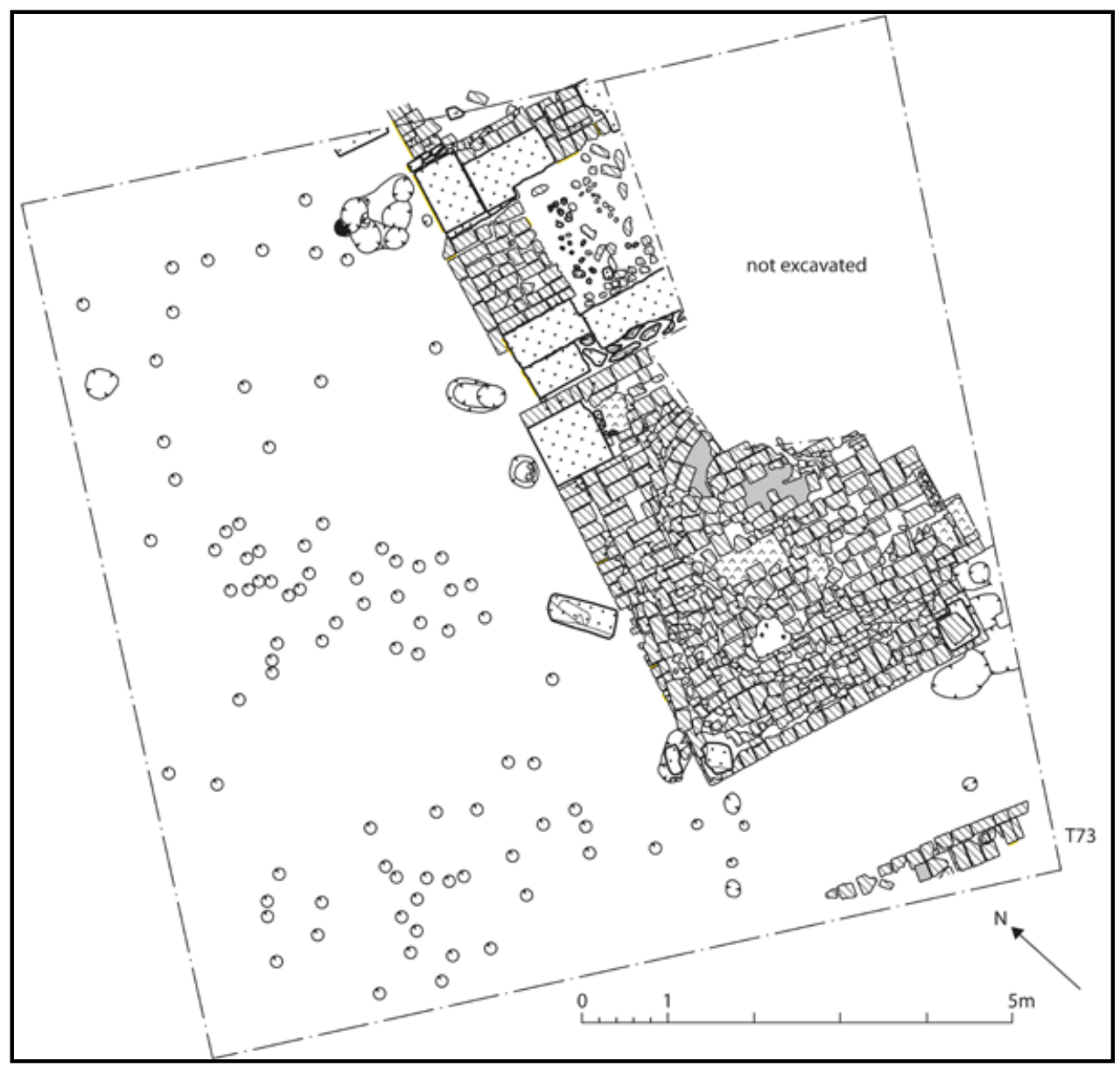

Fig. 3. Top plan of trench T73 at the end of excavations. (Illustration: Pavel Onderka, Vlastimil Vrtal, and Jiří Honzl).

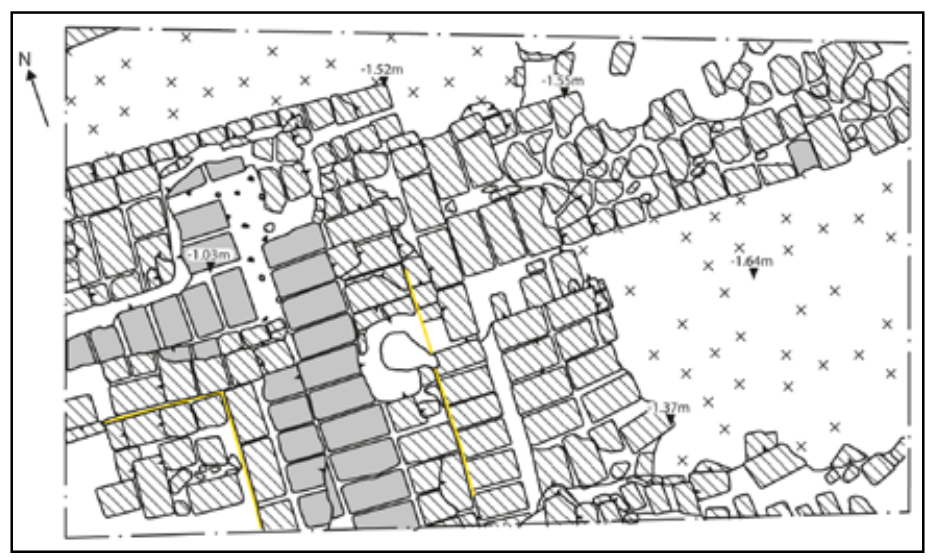

Fig. 4. Top plan of trench $\mathrm{T} 75$ at the end of excavations. (Illustration: Vlatimil Vrtal and Jiří Honzl). 
of the wall itself; the plaster proved to be applied only above the level of the top of the protruding brickwork. The raised foundations were likely used to compensate for the uneven terrain of the area in which the temple was built.

A secondary structure made of fired bricks built right against the plastered walls was identified in the interior of the building (FEA 289). In the eastern part of trench T75, the brick destruction was covering another secondary fired brick structure. Loosely laid brickwork was built against the raised foundations on the eastern outer side of the corner (FEA 292).

Another heavily damaged wall was identified in the north-eastern part of trench T75 (FEA 293). The wall was joining the eastern rear wall of the so-called Isis temple (WBN 300) right to the south of the north-eastern corner of the building. The wall was mostly unpreserved above the level of foundations; only in the part nearest to the wall of the temple a few courses of brickwork remained extant. The wall was built entirely of fired bricks. It was running to the east in the general direction of the south-western corner of the Palace of Amanishakhete (WBN 100). However, it could not be identified with the wall WBN 172 as the exact course of the wall was slightly different, its remaining part was built exclusively of bricks, not employing stones, and also its thickness (ca. $0.9 \mathrm{~m}$ ) was lesser. ${ }^{18}$

\section{Conclusion}

The continued excavation of the so-called Isis Temple (WBN 300) confirmed its expected dimensions. The southern tower of the pylon was found to be overall in better state of preservation than the northern one, even to the point of recovering fragments of its decoration which allowed to recognize the motifs depicted on the building's façade. In the southern part of the pylon, there was also a side entrance to the hypostyle hall.

Thus, it was confirmed that the façade was designed as strictly axial, contrary to the former presumption based on the comparison with ; the Isis Temple at Philae. The inspiration was apparently not literal, as the pattern represented by the Philae Temple was apparently adjusted to fit local Meroitic needs and preferences, likely in similar manner as in the case of the Temple B 300 at Jebel Barkal and the Typhonium (WBN 200) at Wad Ben Naga. ${ }^{19}$

\section{[2] Continued excavations of structure WBN 250}

\section{Trench $T 74$}

Trench T74 $(10.0 \times 5.0 \mathrm{~m})$ was established at the northern limit of so-called kom A covering structure WBN 250. Remains of this monumental structure were previously uncovered in trenches $\mathrm{T} 4,^{20} \mathrm{~T} 36,{ }^{21} \mathrm{~T} 44,^{22}$ and $\mathrm{T} 69 .^{23}$ The structure had an unusual ground plan and was roughly contemporary with the so-called Typhonium (WBN 200), against the northern face of which it was erected. The area covered by trench 
T74 was a northerly extension of trench T69, in which minimum two periods of building activity were identified, as well as considerable debris including large number of fragments of sandstone architectural elements, possibly from an entrance and a hypostyle or a columned portico. The aim of excavations in trench T74 was to test for the extent of the building further to the north ${ }^{24}$ and to uncover additional pieces of sandstone architectural elements.

The trench was divided into two sectors of $5.0 \times 5.0 \mathrm{~m}$ that were excavated separately. Both sectors were marked by the presence of a thick layer of fired brick debris and sandstone detritus (FEA 588), which was gradually removed and documented. The layer was considerably thicker in the western sector, where it formed a small mound. In the eastern sector, the debris included both large sandstone blocks, which were distributed evenly in the stratum, and sandstone chips and detritus, which were situated mainly at the lower limit of the stratum and particularly in the western part of the sector. Similar to the situation in trench T69, the debris was overlying strata corresponding to the previous secondary occupation of the area and consisting of a levelled muddy soil with very little debris (FEA 589). Two fireplaces (FEAs 591 and 596) were noted in this fill. Stratum FEA 589 covered most structural features in the eastern sector of the trench [Fig. 5; Pl. 9]. A bending drainage (FEA 590) was uncovered, which was made of plastered fired bricks embedded into a mortar floor (FEA 592). ${ }^{25}$ Presumably, the drainage had the purpose of leading (rain ?) water off the area (to the north) of structure WBN 250. ${ }^{26}$ It terminated over a large, apparently circular depression (FEA 595) excavated deep in the sāra bedrock. The depression either served as a water reservoir and gradually silted up with mud (FEA 594) or alternatively, it was filled with it deliberately and served as a tree pit, ${ }^{27}$ to which the drainage was bringing water. At some point, the outlet apparently collapsed and a line of fired bricks (FEA 593) was built perpendicular to the shorter wing of the drainage on a thin layer of mud overlying the mortar floor, whose southern limit the brick construction roughly followed.

In the western sector of the trench, the excavations were terminated shortly after reaching the upper level of fired brick and sandstone debris (FEA 588), and the trench was refilled before continuation of works in the following excavation season.

Among the sandstone blocks and chips retrieved from stratum FEA 588, several diagnostic pieces could be identified, complementing the repertoire of sandstone architectural elements and parts of relief decoration program from trench T69. Some fragments preserved parts of various ledges and friezes (?), others could be identified as floral and figural motives. Several stones demonstrably belonged to the same decorative elements as in trench T69: namely a cavetto cornice (S1097, S1100, S1104, S1107, S1116, S1118, S1120, S1126, S1160), a star frieze (S1109, S1151, S1154, S1157), a winged sundisc (S1144, S1146), and a large lotus flower (S1108). Among the figural motives, one fragment (S1124) could be identified as a wrinkled eye of a lion, a ram, ${ }^{28}$ or the god Bes. Another complete block (S1148) preserved

24 Particularly with respect to the orientation of stone wall WBN 171; see Onderka 2016, p. 39, Fig. 2.1.

25 The mortar floor, consisting predominantly of bedrock particles, was situated at the same level as in trench T69 (FEA 566).

26 The drainage declined with the gradient of ca. $0.8^{\circ}$.

27 See particularly Onderka et al. 2017b, pp. 98-99, Fig. 4, Pl. 4; Wolf 2011. See also Macadam 1955, pp. 221-222, Figs. 78, 79; Török 1997, p. 193, Pls. 161, 162; Wolf et al. 2015, p. 123.

28 See inter alia Hintze et al. 1971, Tf. 11c, 25. 


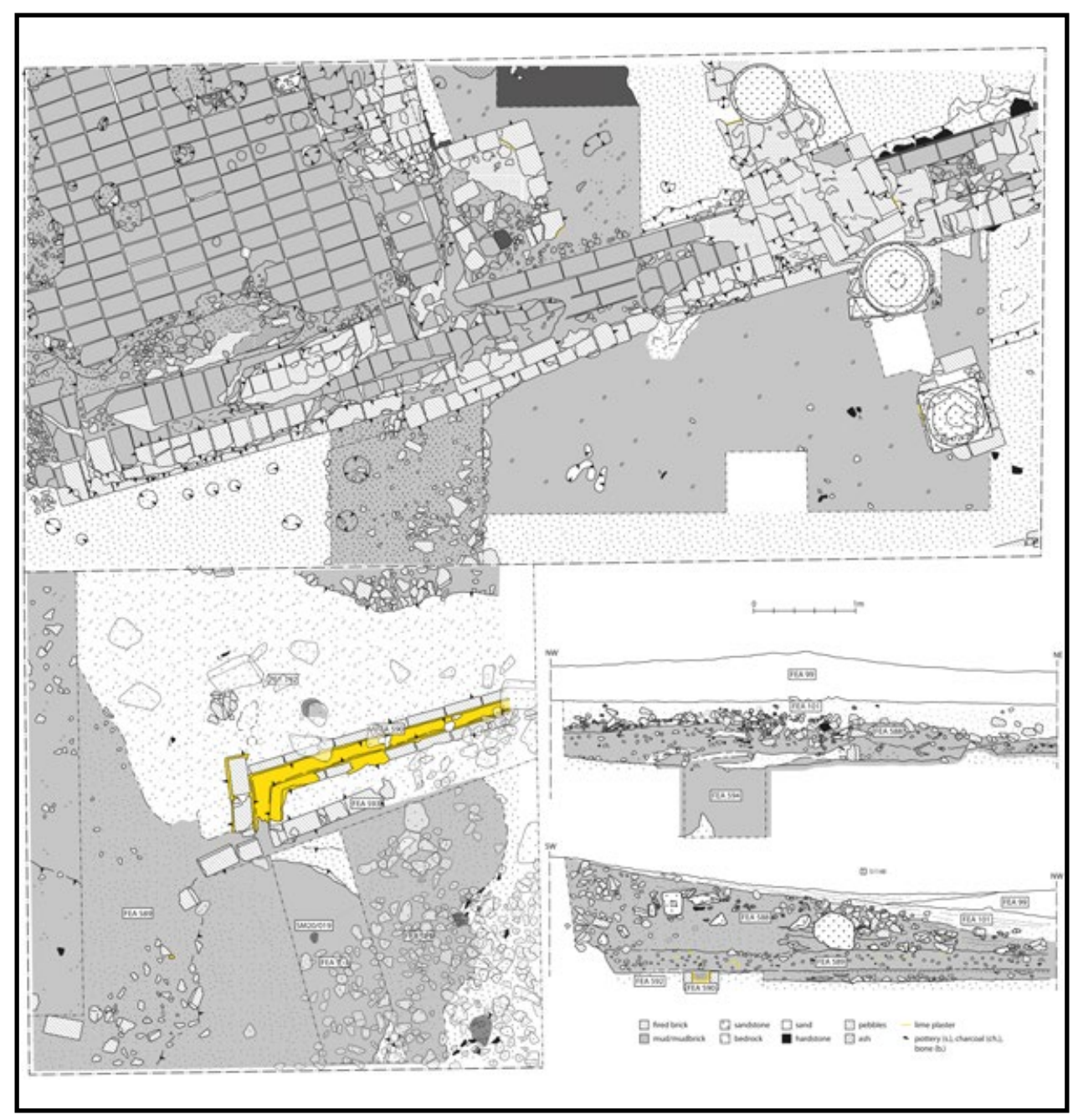

Fig. 5. Top plan of trench T69 and the eastern sector in trench T74 at the end of excavations, overlying debris is marked in lighter ink (top and bottom left); sections north and west in trench T74 (bottom right). (Illustration: Vlastimil Vrtal). 
a depiction of the god Bes, dressed in a lion skin and sticking out his tongue [Pl. 10]. Although the iconographic rendering was very close to the so-called Bes Pillars from the nearby Typhonium (WBN 200), ${ }^{29}$ it is almost certain that the block comes from a different setting. ${ }^{30}$

There is so far no evidence linking the sandstone elements from trenches T69 and T74 to the structural remains of building WBN 250 (with the exception of a single column), on the function of which they might cast some light. On the contrary, the debris in which most sandstone blocks were found and which seemed to come from the north ${ }^{31}$ was overlying strata covering the already denuded exterior wall of the building, ${ }^{32}$ which permits to consider existence of another nearby structure, or a significant post-depositional movement either in the antiquity or in the modern times. ${ }^{33}$

\section{Conclusion}

The excavations at the northern limit of kom A most likely disproved the continuation of structure WBN 250 farther to the north, beyond the exterior wall excavated in trench T69. The structural features uncovered in trench T74 clearly pertained to exterior features, be it a tree pit or a water reservoir. The orientation of the drainage indicated that they might nevertheless originate from the same period of construction activity as structure WBN 250. At the same time, the continued presence of a high number of fragments of sandstone relief decoration, including religious motifs, points to the existence of a cultic (?) structure in the immediate vicinity of the trench, which was to a considerable extent built of stone. As no such structure was indicated through the geophysical survey of the area, ${ }^{34}$ its localization presents a goal of future archaeological research at the site.

\section{[3] Removal of two large sandstone blocks from the Typhonium (WBN 200)}

The recent exploration of the Typhonium (WBN 200), yielded among others a collection of fragments coming from a large stone architrave with relief decoration, which was originally placed over a niche in the temple's hall of offerings (WBN 201). The

29 See inter alia Onderka 2016, 53; Onderka and Vrtal 2018, pp. 416-417.

30 All the historical depictions of the Bes Pillars that provided greater detail uniformly show that the blocks of the northern pair divided the heads of Bes figures horizontally in half and that a vertical break was present only either on the lower half of the head (eastern and western sides) or on the upper half of the head (northern and southern sides); see Onderka 2016, Pls. 2-4, 7-9. Only one of the Bes Pillars from the southern pair was preserved in the $19^{\text {th }}$ century; in this case, the head of the Bes figure appears to be made of a single block on all four sides, see Onderka 2016, Pl. 7. Unlike any of the blocks on the Bes Pillars, block S1148 covers the right half of the Bes figure from the forehead to the chest. The argument is further supported by the smaller size of the depiction. Berghoff stated that the Bes Pillars were $1.25 \mathrm{~m}$ wide, see Berghoff 1883, p. 24. This observation was roughly confirmed by recent excavation of their bases $(1.17 \mathrm{~m})$, see Onderka and Vrtal 2014; Onderka et al. 2015, p. 96; Onderka and Vrtal 2018. Block S1148 was ca. $0.24 \mathrm{~m}$ wide and despite the god missing part of his shoulder, the original figure must have had the width of only ca. $0.6 \mathrm{~m}$.

See Onderka et al. 2021, Fig. 5, section west.

See Onderka et al. 2021, pp. 75-76.

See stone elements on the northern limit of kom A, Cailliaud 1823, Pl. IX.

Ullrich et al. 2018, Pls. 5-6. 
smaller pieces of the architrave were moved into the store, while the two largest ones were, due to their size and weight, left in their original position. Using the method of 3D-scaning, the original appearance of the architrave could be reconstructed. ${ }^{35}$ In course of the current season, the two blocks were removed from the sanctuary to the house of the ghafir in preparation for their transport to the SNM (Inv. No. 36347), where they are going to be exhibited in the new display of the museum. The stratigraphic layer uncovered by the removal of the stone fragments was excavated and pottery, faience beads, as well as minute fragments of golden foil coming from the gilded decoration features of the offering hall were retrieved.

\section{Literature:}

Berghoff, C. (1883). Ein Ausflug nach Meroe. Globus, 43, pp. 22-27.

Cailliaud, F. (1823). Voyage a Méroé, au fleuve blanc, au dela de Fâzoql dans le midi du Royaume de Sennâr, a Syouah et dans cinq autres oasis. Paris.

Erbkam, G. G. (2007). Tagebuch meiner egyptischen Reise, in der Transkription von Elke Freier, unter Mitarbeit von Stefan Grunert. [online] Available at: http://pom.bbaw.de/ erbkam/. [Accessed on 21 Jan. 2021].

Gamer-Wallert, I. (1983). Der Löwentempel von Naq'a in der Butana (Sudan) III: die Wandreliefs. Beihefte zum Tübinger Atlas des Vorderen Orients, Reihe B (Geisteswissenschaften) 48 (3). Wiesbaden.

Garstang, J. (1911). Meroë, the city of the Ethiopians: being an account of a first season's excavations on the site, 1909-1910. Oxford.

Hintze, F., Hintze, U., Priese, K.-H. and Stark, K. (1971). Musawwarat es-Sufra. Band I, 2. Der Löwentempel. Tafelband. Berlin.

Jungová, G. (2020). Burials from Cemetery Wad Ben Naga C260 - First Report. Annals of the Náprstek Museum, 41(2), pp. 155-167.

Kurth, D. (1975). Den Himmel stützen: die "tww pt"-Szenen in den ägyptischen Tempeln der Griechisch-römischen Epoche. Rites égyptiens 2. Bruxelles.

Lepsius, R. (1849-1859). Denkmäler aus Ägypten und Äthiopien. Nach den Zeichnungen der von Seiner Majestät dem Könige von Preussen, Friedrich Wilhelm IV., nach diesen Ländern gesendeten und in den Jahren 1842-1845 ausgeführten wissenschaftlichen Expedition, XII Vols. Berlin.

Macadam, M. F. L. (1955). The temples of Kawa II. History and archaeology of the site. London.

35 Onderka et al. 2014a, p. 13, Pl. 2. 
Onderka, P. (2012). Preliminary report on the third excavation season of the Archaeological Expedition to Wad Ben Naga. Annals of the Náprstek Museum, 33, pp. 117-134.

Onderka, P. (2013). Preliminary report on the fourth excavation season of the Archaeological Expedition to Wad Ben Naga. Annals of the Náprstek Museum, 34/1, pp. 3-14.

Onderka, P. (2015). The typhonia of Frédéric Cailliaud. In J. Mynářová, P. Onderka, and P. Pavúk (eds), There and back again - the crossroads II: proceedings of an international conference held in Prague, September 15-18, 2014. Prague, pp. 447-463.

Onderka, P. (2016). Wad Ben Naga Report I: An Introduction to the Site. Prague.

Onderka, P. and Vrtal, V. (2014a). Preliminary report on the seventh excavation season of the Archaeological Expedition to Wad Ben Naga. Annals of the Náprstek Museum, 35(2), pp. 9-20.

Onderka, P. and Vrtal, V. (2018). The Typhonium of Wad Ben Naga. In: M. Honegger (ed.), Nubian archaeology in the XXIst century. Proceedings of the Thirteenth International Conference for Nubian Studies, Neuchâtel, 1st-6th September 2014. Leuven - Paris - Bristol, pp. 415-422.

Onderka, P., Vrtal, V. and Gatzsche, A. (2017b). Preliminary report on the twelfth excavation season of the Archaeological Expedition to Wad Ben Naga. Annals of the Náprstek Museum, 38(1), pp. 113-122.

Onderka, P., Vrtal, V. and Gatzsche, A. (2017a). Preliminary report on the thirteenth excavation season of the Archaeological Expedition to Wad Ben Naga. Annals of the Náprstek Museum, 38(2), pp. 93-104.

Onderka, P., Vrtal, V. and Gatzsche, A. (2018a). Preliminary report on the fourteenth excavation season of the Archaeological Expedition to Wad Ben Naga. Annals of the Náprstek Museum, 39(1), pp. 95-108.

Onderka, P., Vrtal, V. and Honzl, J. (2019a). Preliminary report on the sixteenth excavation season of the Archaeological Expedition to Wad Ben Naga. Annals of the Náprstek Museum, 40(1), pp. 133-147.

Onderka, P., Vrtal, V. and Jungová, G. (2018b). Preliminary report on the fifteenth excavation season of the Archaeological Expedition to Wad Ben Naga. Annals of the Náprstek Museum, 39(2), pp. 137-148.

Onderka, P., Vrtal, V. and Jungová, G. (2019b). Preliminary report on the seventeenth excavation season of the Archaeological Expedition to Wad Ben Naga. Annals of the Náprstek Museum, 42(1), pp. 67-83. 
Onderka, P., Vrtal, V., Jungová, G. and Honzl, J. (2021). Preliminary report on the eighteenth excavation season of the Archaeological Expedition to Wad Ben Naga. Annals of the Náprstek Museum, 41(2), pp. 107-120.

Onderka, P., Vrtal, V. et al. (2014b). Nubia. A Land on the Crossroads of Cultures: Wad Ben Naga 2014. Prague.

Priese, K.-H. (1984). Der Isistempel von Wad Ban Naqa. In F. Hintze, ed., Meroitistische Forschungen 1980: Akten der 4. internationalen Tagung für meroitistische Forschungen vom 24. bis 29. November 1980 in Berlin. Berlin, pp. 347-350.

Rocheleau, C. M. (2008). Amun temples in Nubia: a typological study of New Kingdom, Napatan and Meroitic temples. BAR International Series 1850. Oxford.

Török, L. (1997). Meroe City, an ancient African capital: John Garstang's excavations in the Sudan. Egypt Exploration Society, Occasional Publications 12 (1-2). London.

Ullrich, B., Onderka, P. and Vrtal, V. (2018). Preliminary Report on the Geophysical Survey of Central Wad Ben Naga. Annals of the Náprstek Museum 39(2), pp. 119-136.

Wolf, P. (2011). Der Garten der Großen Anlage von Musawwarat es-Sufra, Sudan. In S. Kappel and C. E. Loeben (eds), Gärten im alten Ägypten und in Nubien 2000 v. Chr. -250 n. Chr. Rahden, Westfalen, pp. 29-37.

Wolf, P., Nowotnick, U. and Hof, C. (2015). Hamadab - insights into development and lifestyle of a Meroitic urban settlement. In M. H. Zach (ed.), The Kushite world: proceedings of the 11th international conference for Meroitic studies, Vienna, 1-4 September 2008. Vienna, pp. 123-139. 


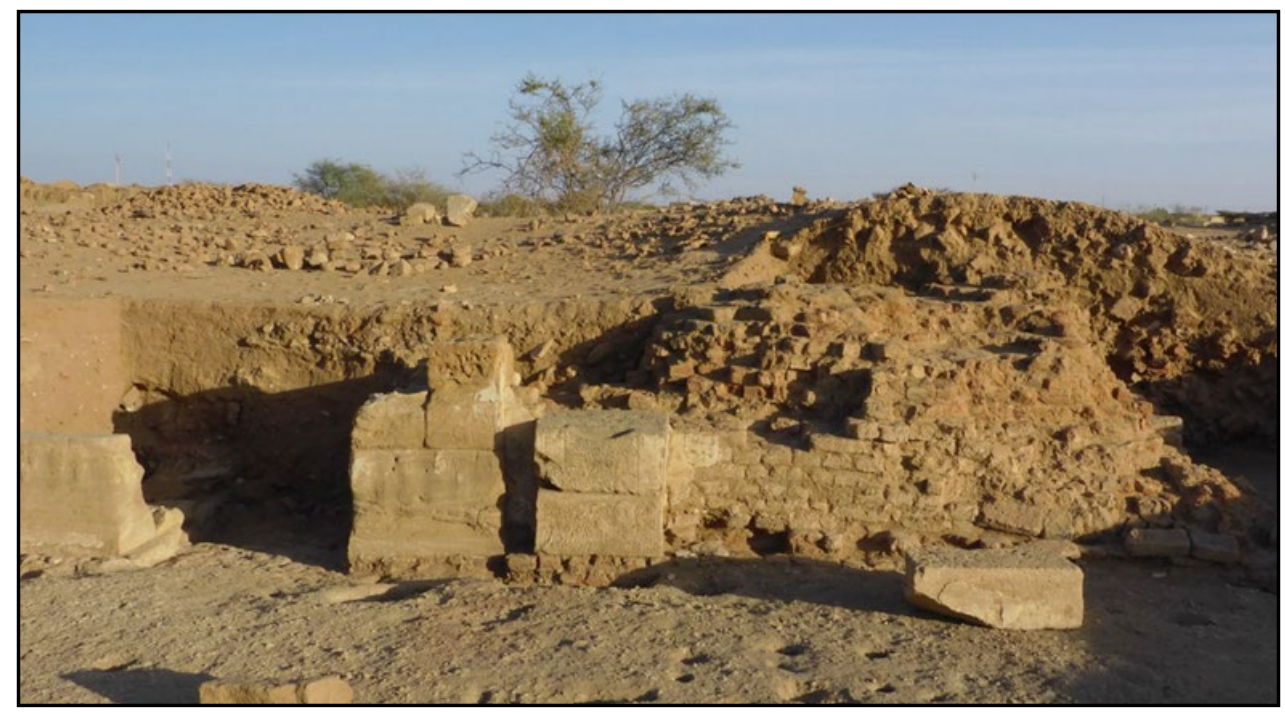

Pl. 1. View on the southern tower of the pylon of the socalled Isis Temple at Wad Ben Naga (WBN 300).

(Photo: Pavel Onderka).

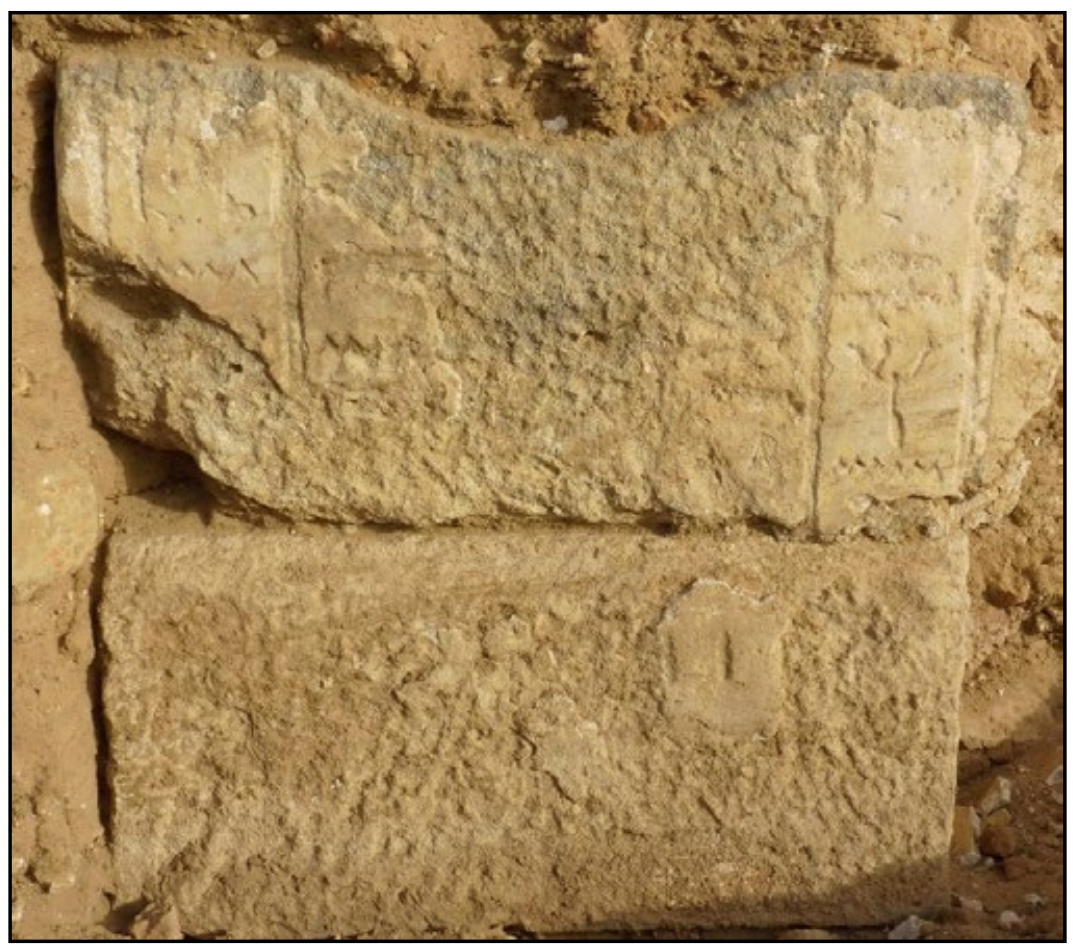

Pl. 2. The pillar formed by two ferriferous sandstone blocks with an inscription in Egyptian hieroglyphs. (Photo: Pavel Onderka). 
Pl. 3
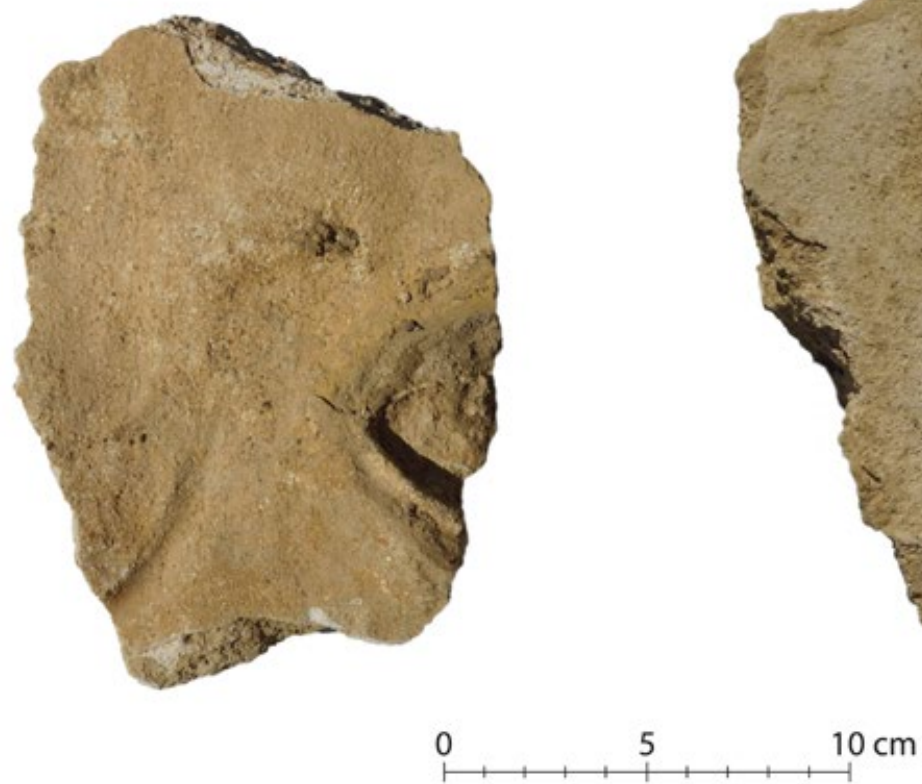

Pl. 4

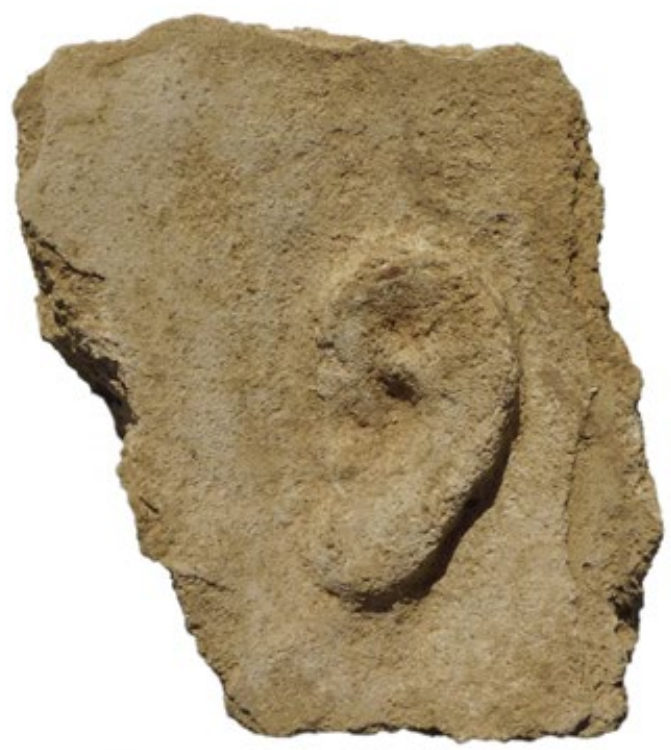

$10 \mathrm{~cm}$
P1. 5

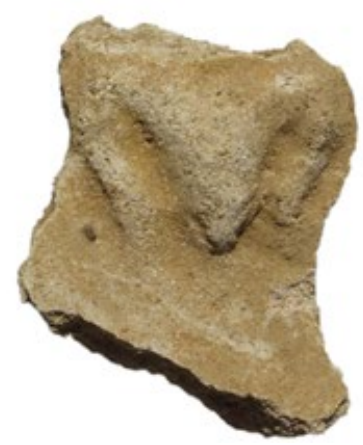

P1. 6

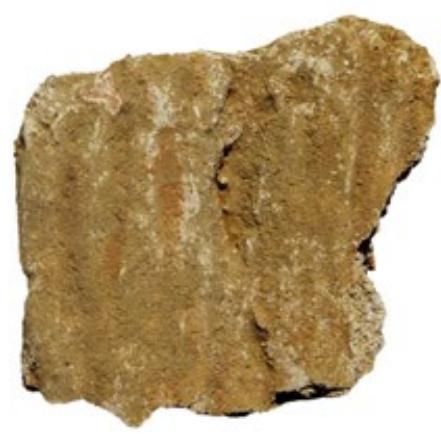

Pls. 3-6. Fragments of plaster from the façade of the pylon's southern tower depicting a human eye, a human ear, a pendant in the form of a ram's head, and fingers of two human hands. (Photo: Pavel Onderka). 


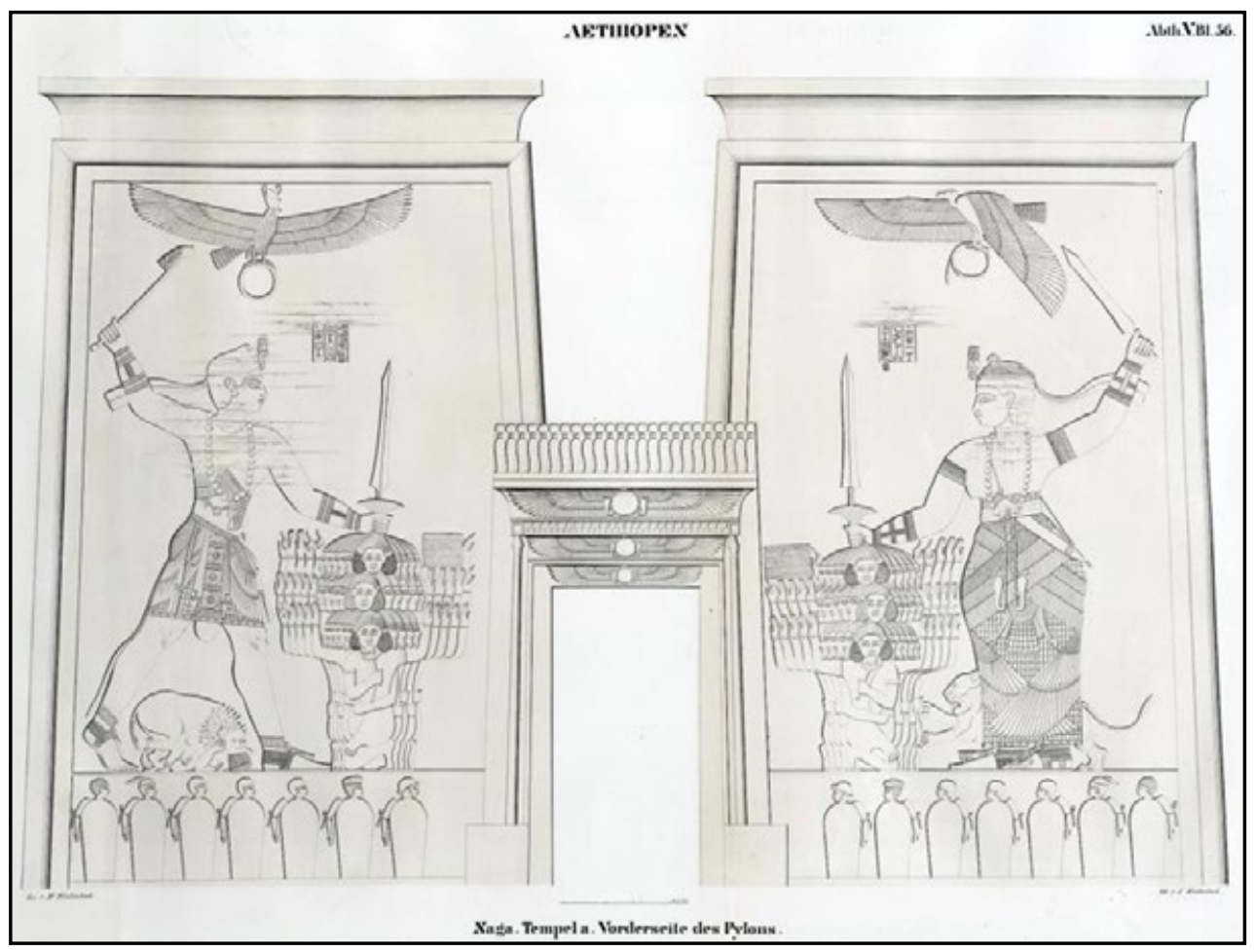

Pl. 7. Line drawing of the pylon of the Lion Temple at Naga. (Lepsius 1949-1959, X, Taf. 56).

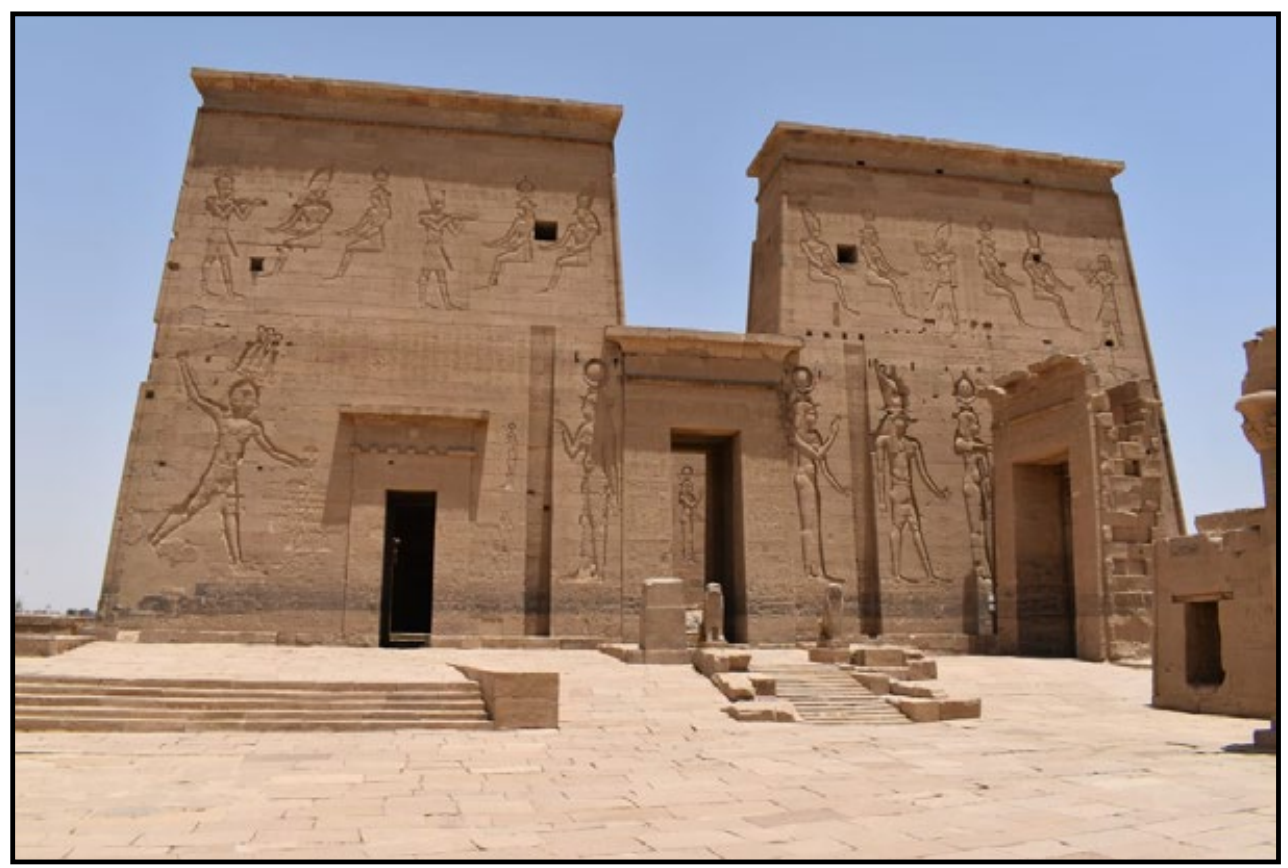

Pl. 8. The First Pylon of the Isis Temple at Philae. (Photo: Pavel Onderka). 


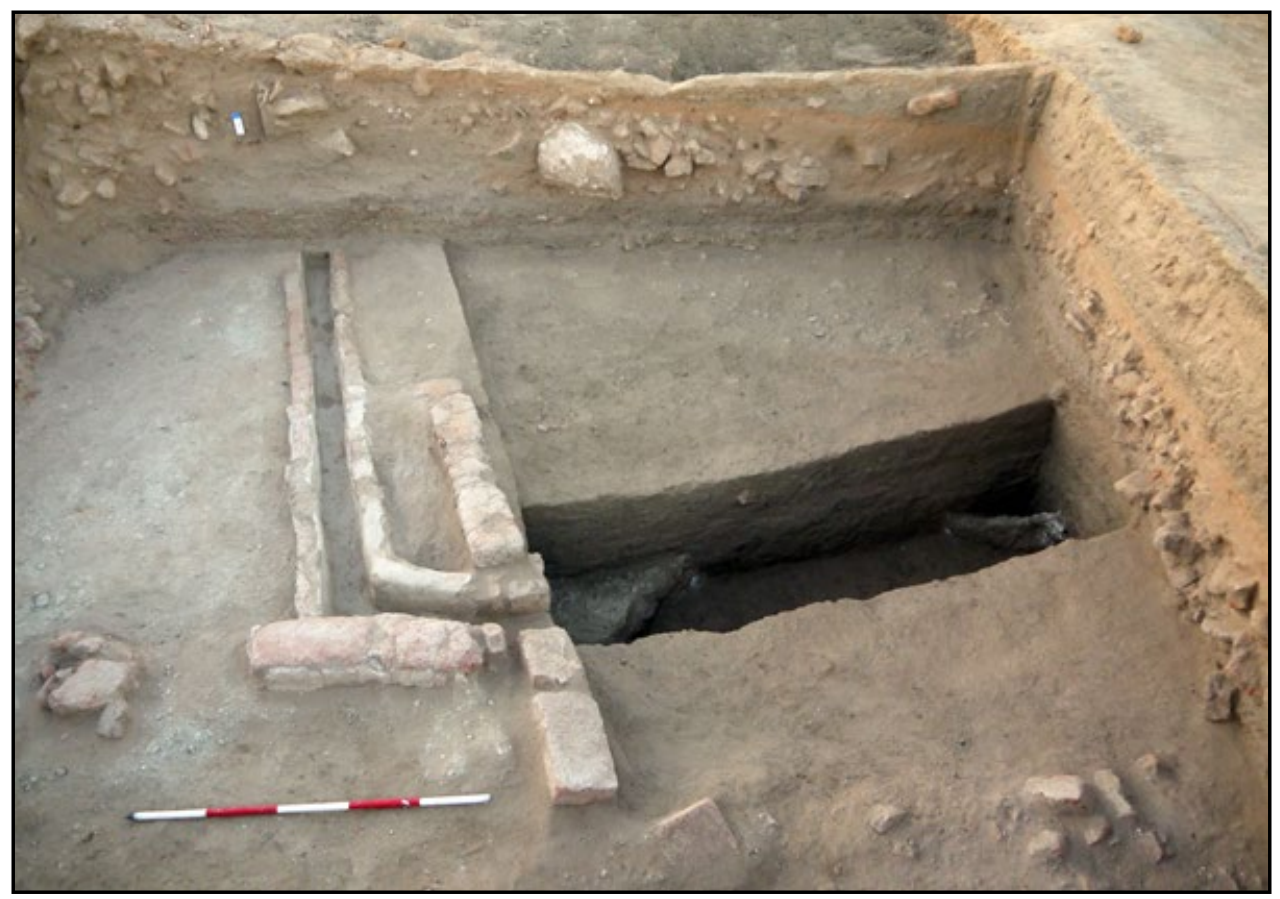

P1. 9. Selected fragments of sandstone reliefs with figural motives. (Photo: Vlastimil Vrtal).

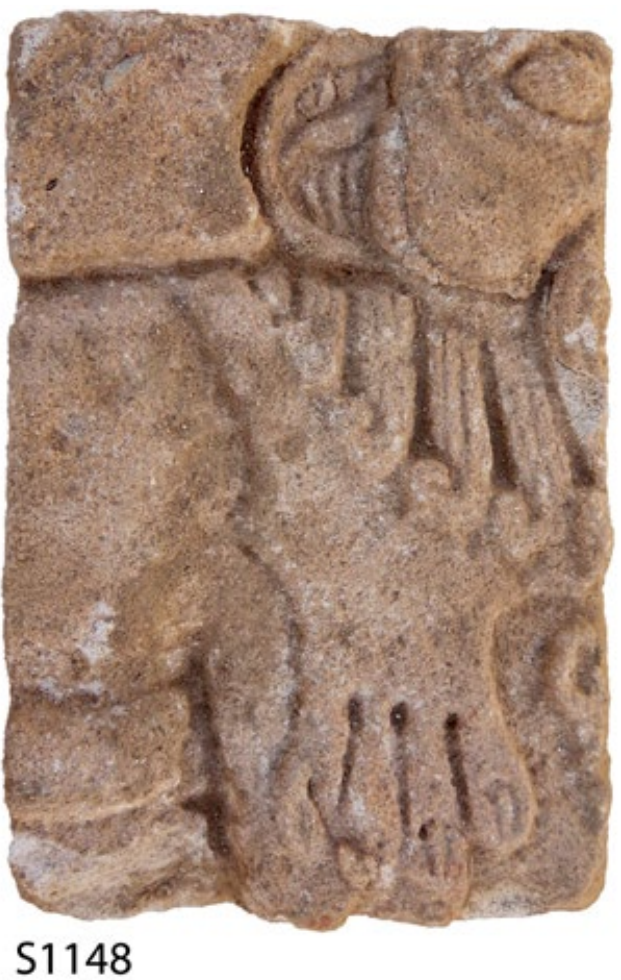

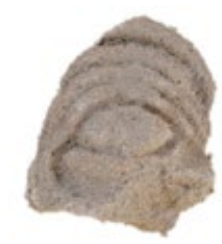

S1124

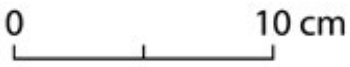

Pl. 10. The eastern sector in trench T74 at the end of excavations, view towards the west; position of stone S1148 marked with label on the section west. (Photo: Vlastimil Vrtal). 